\title{
Influence of environmental variables on seasonal abundance and relative growth of Macrobrachium amazonicum (Crustacea: Decapoda: Caridea): variations of a continental population
}

\author{
Alessandra A. P. Bueno' (D), Carolina R. Bonatto' (i) \& Ariádine C. Almeida² (D)
}

\begin{abstract}
1. Universidade Federal de Lavras (UFLA), Programa de Pós-Graduação em Ecologia Aplicada, Departamento de Biologia, Laboratório de Carcinologia, Campus Universitário, 37200-000 Lavras, MG, Brazil. (aapbueno@yahoo.com.br)

2. Universidade Federal de Uberlândia, Instituto de Biologia, Campus Umuarama, Av. Pará, 1920, 38400-902 Uberlândia, MG, Brazil. (ariadinecalmeida@gmail.com)
\end{abstract}

Received 27 August 2018

Accepted 3 April 2019

Published 23 May 2019

DOI 10.1590/1678-4766e2019018

\begin{abstract}
The aim of the present study was to evaluate the influence of abiotic factors (conductivity, dissolved oxygen, $\mathrm{pH}$, precipitation, and water temperature) on the abundance of Macrobrachium amazonicum (Heller, 1862), as well as to compare the relative growth among demographic groups throughout the seasons in a lagoon system located in the municipality of Perdões, Minas Gerais. Monthly, from August/2013 to July/2014, the prawns were collected on macrophytes of the genus Eichhornia using a semi-circular sieve. In the laboratory, the specimens were categorized into juveniles, males, ovigerous females and non-ovigerous females, and measured as total length (TL), carapace length (CL), and abdomen length (AL). The predominance of juveniles was evident, representing $74.4 \%$, followed by $16.7 \%$ males, $2.8 \%$ ovigerous females and $6.1 \%$ non-ovigerous females. The total abundance and the abundance of juveniles, males, and females were negatively correlated with conductivity. The relative growth of TL and AL, in relation to CL, was different for juveniles, males and females thought the year, except during summer (for TL and AL) and autumn (for AL), when the same pattern was observed for the three demographic categories ( $p>0.05$ ), possibly due to the highest abundance of juvenile individuals obtained in these seasons. The highest abundance of juveniles can be related to its occurrence in microhabitats that provide refuge, as Eichhornia. Despite some similar characteristics here observed in relation to the other populations throughout its distribution, as the high number of juveniles and the smaller size of males compared to females, the present study provides information that expands the knowledge on the plasticity of M. amazonicum, considering the sampled local - a lateral lagoon system. The obtained results promote the comprehension of the vast occurrence of the species and its adaptations to each specific environment, contributing to the elaboration of conservation and management guidelines for M. amazonicum and for the environment where it inhabits.
\end{abstract}

KEYWORDS. Abiotic variables, demographic categories, freshwater prawn, phenotypic plasticity.

RESUMO. Influência de variáveis ambientais na abundância sazonal e crescimento relativo de Macrobrachium amazonicum (Crustacea: Decapoda: Caridea): variações de uma população continental. O objetivo do presente estudo foi avaliar a influência de fatores abióticos (condutividade, oxigênio dissolvido, pH, precipitação e temperatura da água) na abundância de Macrobrachium amazonicum (Heller, 1862), bem como comparar o crescimento relativo entre as categorias demográficas ao longo das estações do ano, em uma lagoa marginal localizada no município de Perdões, em Minas Gerais. Os camarões foram coletados mensalmente, de agosto de 2013 a julho de 2014, em macrófitas do gênero Eichhornia com o uso de uma peneira semicircular. No laboratório, os espécimes foram categorizados em juvenis, machos, fêmeas e fêmeas ovígeras, e medidos quanto ao comprimento total (CT), comprimento da carapaça (CC) e comprimento do abdome (CA). O predomínio de juvenis foi evidente, representando 74,4\%, seguido por 16,7\% machos, $6,1 \%$ fêmeas e 2,8\% fêmeas ovígeras. A abundância total e a abundância de juvenis, machos e fêmeas foram correlacionadas negativamente com a condutividade. $\mathrm{O}$ crescimento relativo do $\mathrm{CT}$ e CA, em relação ao CC, foi diferente para juvenis, machos e fêmeas ao longo de todo ano, exceto durante o verão (para CT e CA) e o outono (para CA), quando o mesmo padrão foi observado para as três categorias demográficas (p>0,05), possivelmente devido à maior abundância de indivíduos jovens obtida durante estas estações. Esta maior abundância de juvenis pode estar relacionada à sua ocorrência em microhabitats que forneçam refúgio como Eichhornia. Apesar de algumas características semelhantes aqui observadas em relação às demais populações ao longo de sua distribuição geográfica, como o elevado número de juvenis e o menor tamanho dos machos em comparação às fêmeas, o presente estudo fornece informações que ampliam o conhecimento sobre a plasticidade de M. amazonicum, principalmente com relação ao local de amostragem - uma lagoa marginal. Desta forma, os resultados obtidos ampliam a compreensão sobre a vasta ocorrência da espécie e suas respectivas adaptações nos mais variados habitats, contribuindo para a elaboração de diretrizes de conservação e manejo para M. amazonicum e para o meio que habita.

PALAVRAS-CHAVE. Camarão de água doce, categorias demográficas, plasticidade fenotípica, variáveis abióticas.

Inserted in the infraorder Caridea, the genus Macrobrachium Bate, 1868 presents species of commercial importance that are exploited both in their natural environment as through aquaculture, as Macrobrachium amazonicum (Heller, 1862) (Odinetz-COLLART, 1993; Odinetz-Collart \& Moreira, 1993; Buckup \& Bond-
Buckup, 1999; Mantelatto \& Barbosa, 2005). This is an endemic species of the South America, with records in nine countries, including Brazil, covering the Amazonas, Araguaia-Tocantins, São Francisco and La Plata hydrographic basins (MACIEl \& VALENTI, 2009; Vergamini et al., 2011; PILEGGi et al., 2013). 
Due to the wide geographic distribution of the species, in association to the diversity of habitats colonized by it, as floodplain lagoons, lakes, rivers, and water dams (Maciel \& VAlenti, 2009), population variations can be observed along the twenty Brazilian states where this species occurs, including variations of the abundance, growth and reproduction (ODINETZ-COLLART, 1988; BUCKUP \& BONDBuckup, 1999; Moraes-Valenti et al., 2010; Pileggi et al., 2013).

However, it is known that significant genetic divergence among populations of $M$. amazonicum was considered to classify them into three groups, as proposed by Vergamini et al. (2011): I) inland waters of the Amazonian Hydrographic Region, II) Paraná/Paraguay Hydrographic Region and III) Coastal systems of northern and northeastern Brazil. Interestingly, all populations form a single monophyletic clade, supporting their characterization as a single species.

In the northern and northeastern of Brazil, the fishery of M. amazonicum is quite widespread (MACIEL \& VALENTI, 2009), presenting high economic, nutritional, and cultural values (ODINETZ-COLlaRT, 1993; BENTES et al., 2011). On the other hand, due to cultural differences and/or different biological features of the species (e.g., smaller body size), the populations occurring in the region comprising the Paraná-Paraguay Basin are used only as fish baits (MACIEL \& VALENTI, 2009). Besides its economic importance in some Brazilian regions, another factor justifying the interest in M. amazonicum is the plasticity showed by the species (OdinetZ-Collart, 1988; OdinETZ-Collart, 1991; MACIEL \& VALENTI, 2009; Moraes-VALENTI et al., 2010; Vergamini et al., 2011). Among natural populations, it is possible to observe many morphological variations, specially related to body size (MACIEL \& VALENTI, 2009; Vergamini et al., 2011). These differences may be due to environmental factors, such as hydrological and physical features (ODINETZ-COLLART, 1988; MACIEL \& VALENTI, 2009). Thus, environmental factors may promote or limit the distribution of individuals, affecting the population dynamics.

With respect to the continental environments, the construction of reservoirs favored the expansion of limnological knowledge (e.g. TuNDISI, 1988; HeNRY, 1999; TUNDISI \& StraŠKRABA, 1999; NogueIra et al., 2006), although this is still limited in relation to the structure and functioning of this type of ecosystem (KENNEDY et al., 2003). An important example, with few studies carried out, is on the reservoir filling up process and the consequent artificial lateral lagoons formation and its interactions (HENRY et al., 2006; Bicudo et al., 2006). According to the PIECZYNSKA (1995), the lateral lagoons are highly productive, exhibit numerous microhabitats and are colonized by rich assemblages of plants, invertebrate and vertebrate fauna. Therefore, these environments have an important role for the biodiversity maintenance of the entire fluvial ecosystem (SENDACZ \& MONTEIRO-JÚNIOR, 2003; BAUMGARTNER et al., 2004).

Considering the wide distribution and phenotypic plasticity showed by M. amazonicum, in association with the complex dynamics of lateral lagoons, the aim of this study was to evaluate its abundance and temporal distribution in the Mangueira Lagoon, at Perdões municipality, in the State of Minas Gerais, Brazil. The relationship between abiotic factors (conductivity, dissolved oxygen, $\mathrm{pH}$, precipitation, and water temperature) and abundance was also analyzed. The relative growth of body length and abdomen length, in relation to the cephalothorax length, was compared between demographic categories and seasons. Based on the results, we expect to understand the dynamics influence of this ecosystem on the abundance and growth of this species, providing new information for the comprehension of Macrobrachium amazonicum phenotypic plasticity.

\section{MATERIAL AND METHODS}

Study site and sampling. Samplings were carried out in the Mangueira lagoon, at Perdões municipality, Minas Gerais State (2109'32.1”S; 4508'56.6”W) (Fig. 1). This lagoon is surrounded by meadow used by beef cattle, and it is located approximately $150 \mathrm{~m}$ from the Rio Grande river. Perdões is located in the west region of the Minas Gerais State (IBGE, 1990), and inserted in the Rio Grande subbasin, southeastern Brazil. The Rio Grande basin belongs to the Paraná River hydrographic region, which is the third largest basin of the Brazilian territory. The lagoon connects to the river (Rio Grande) only in periods of intensive floods. The annual mean rainfall in the municipality is $1,455 \mathrm{~mm}$ (CLIMATE-DATA.ORG, 2018).

Importantly, a pilot study was carried out to obtain specimens for identification, which was performed by researchers of the Laboratory of Bioecology and Systematics of Crustaceans (LBSC), University of São Paulo (USP). These researchers used specific literature (i.e. HoLthuis, 1952; García-DÁvila \& Magalhães, 2003; Melo, 2003) and confirmed the occurrence of a single species, M. amazonicum.

The prawns were sampled monthly from August $/ 2013$ to July/2014 (IBAMA, License N. 19356-1), on the lagoon margins where Eichhornia Kunth macrophyte banks were abundant, at depths of up to $0.7 \mathrm{~m}$. The specimens were captured with a semi-circular sieve $(80,0 \mathrm{~cm}$ of diameter, $18,0 \mathrm{~cm}$ height, and $1,0 \mathrm{~mm}$ mesh size) that was placed at the bottom of the macrophytes, and quickly lifted up to the surface. This procedure was repeated 15 times by one person along the macrophyte banks, during the vespertine period. Prior to the prawns caught, the physicochemical water parameters, temperature $\left({ }^{\circ} \mathrm{C}\right)$, dissolved oxygen $(\mathrm{mg}$ $\left.\mathrm{l}^{-1}\right)$, conductivity $\left(\mu \mathrm{Scm}^{-1}\right)$, and $\mathrm{pH}$, were taken monthly using specific digital portable meters (HANNA Instruments). The precipitation values $(\mathrm{mm})$ were also obtained from Main Climatological Station of Lavras, managed by the Universidade Federal de Lavras.

After samples, the individuals were stored in plastic pots and transported with ice bags to the Laboratory of Carcinology of the Universidade Federal de Lavras. Once ovigerous females were captured, they were individualized in smaller plastic pots. In the laboratory, the specimens were 


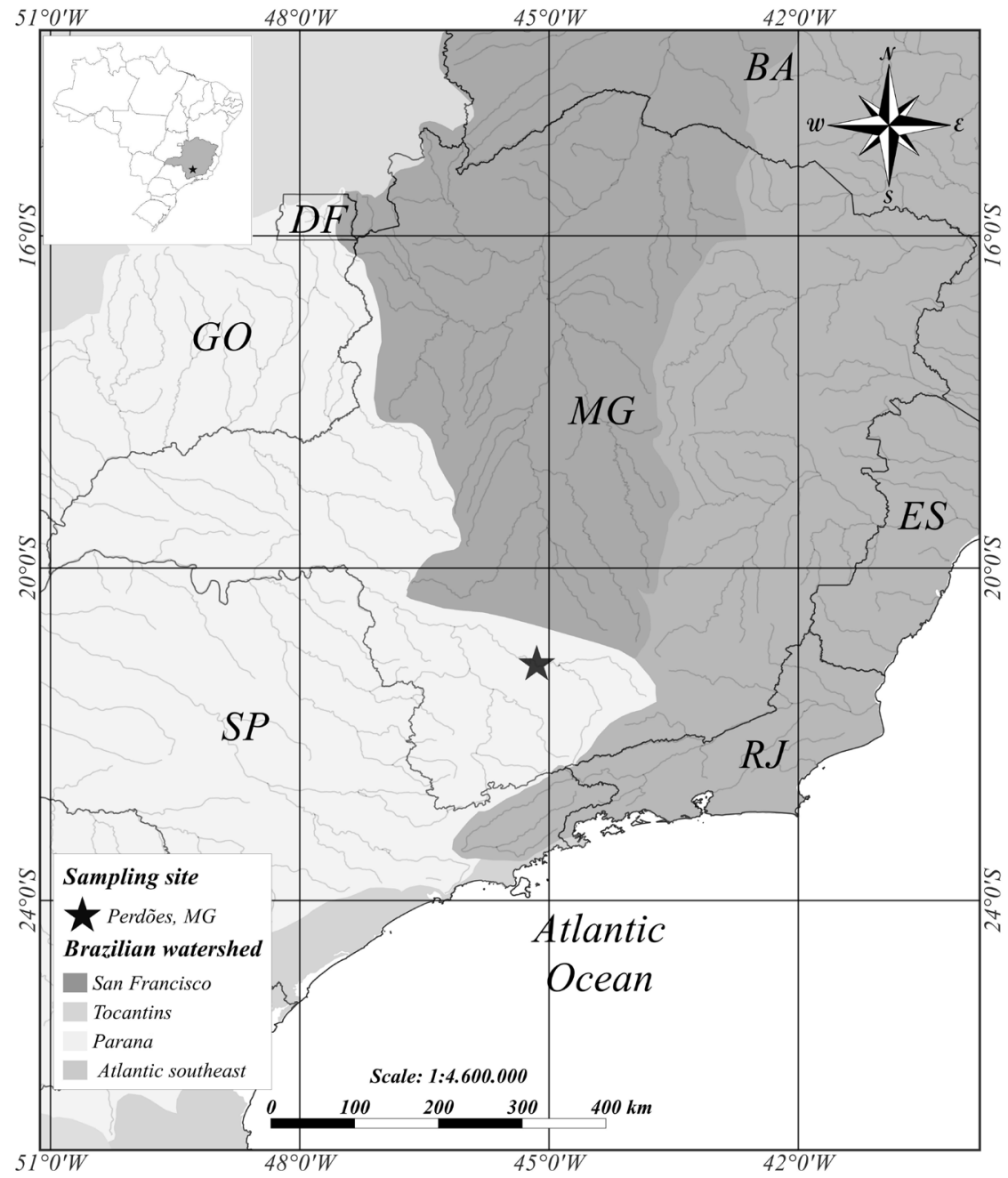

Fig. 1. Location of Perdões municipality in the State of Minas Gerais, Brazil.

sexed, according with the presence/absence of appendix masculine on the second pair of pleopods (MANTELATTO \& BARBOSA, 2005), and measured using a stereomicroscope equipped with micrometric ocular ( $0.01 \mathrm{~mm}$ accuracy). The following measures were taken: total length (TL, distance between the anterior margin of the rostrum and the posterior margin of the telson), carapace length (CL, distance between the posterior margin of the orbit and the median point of the carapace posterior margin) and abdomen length (AL, distance between the posterior margin of the carapace and posterior margin of the abdomen). After, the specimens were classified as juveniles (individuals with CL smaller than that of the smaller ovigerous female), males (specimens with appendix masculine on the second pair of pleopods), ovigerous females (females with eggs attached to the pleopods), and nonovigerous female (specimens without appendix masculine on the second pair of pleopods).

Data analysis. The total abundance, the abundance per group and between juveniles and adults along the seasons was tested for normality and homoscedasticity using the Shapiro-Wilk test $(\alpha=0.05)$. When necessary the data were log-transformed. The seasons defined were summer (from
January to March), autumn (from April to June), winter (from July to September) and spring (from October to December).

The mean total abundance and by demographic category were compared between seasons using analysis of variance (one-way ANOVA, $\alpha=0.05$ ). In order to compare the mean number of juveniles and adults in each season, the Student's t-test was used $(\alpha=0.05)$.

Hierarchical partitioning analyses (CHEVAN \& Sutherland, 1991) were used to evaluate the relative contribution of the abiotic factors on the total abundance, and on the abundance of each demographic category. The hierarchical partitioning analysis considers all possible linear models for a multivariate regression, in order to independently identify the percentage variation explained by each causal factor (Chevan \& Sutherland, 1991; MacNally 2000, 2002). The models were run using the hier.part package (WALSH \& MACNALLY, 2015), which is free for the statistical software R (R Development Core Team, 2013).

Using the log-transformed size measurements (TL, $\mathrm{CL}$, and $\mathrm{AL}$ ), the analysis of relative growth was performed for the demographic category - juveniles, males and females (ovigerous and non-ovigerous) - and season. Analyses were 
based on the linear equation $\ln y=\ln a+b \ln x$ (HARTNOLL, 1978), where " $x$ " is the independent variable (CL), " $y$ " is the dependent variable (TL and AL), "a" is the intercept of $y$ axis, and " $b$ " is the coefficient of allometric growth. The slopes and intercepts of each group were compared with an analyses of covariance (ANCOVA; $\alpha=0.05$ ). The Student's t-test ( $\alpha=0.05)$ (ZAR, 1999) was used to define the growth constant as isometric $(b=1)$, allometric negative $(b<1)$, or allometric positive $(b>1)$ (HuXLEY, 1950). Individuals with imperfections in the rostrum or telson were excluded from this analysis.

\section{RESULTS}

The total abundance by demographic category and their respective carapace length (minimum, medium, and maximum) are shown in Tab. I. Juveniles represented 74.4\% of the population, males represented $16.7 \%$, ovigerous females $2.8 \%$ and non-ovigerous females $6.1 \%$.

Observing the monthly variation in abundance and the percentage for each demographic category it is possible to observe that in June and July 2014 no animals were captured (Fig. 2). Four peaks of highest abundance occurred in August, September, and November 2013, and in January 2014. The predominance of juveniles was evident in this population, and the highest percentage occurred in January, February, April, and May. Adults were not very abundant, but were present through all the study period. Males and non-ovigerous females were more frequent in December 2013, while ovigerous females were more abundant in March 2014. However, the differences between the total abundance and the abundance by demographic category throughout the seasons were not statistically significant (ANOVA, $\mathrm{p}>0.05$ ).
The number of juveniles and adults was also not different between seasons (Student's t-test, $\mathrm{p}>0.05$ ).

Monthly differences in the abiotic factors and their mean annual values are shown in Tab. II. The hierarchical partitioning analysis demonstrated that, among the five abiotic factors measured, conductivity was negatively related with the total abundance (Fig. 3) and with almost demographic categories (Figs 4-6), except for the ovigerous females (Fig. 7). Therefore, it can be assumed that, as the conductivity increases, the total number of individuals decreases, as well as the number of juveniles, males, and non-ovigerous females. Importantly, besides conductivity, $\mathrm{pH}$ also influenced negatively the abundance of non-ovigerous females (Figs 6, 7).

Of the total 2,492 individuals analyzed, 28 were removed from the analysis of relative growth due to the imperfections in the rostrum or telson, being two males, two females and 24 juveniles. The analysis of covariance showed significant differences for the morphometric relationships CL vs TL and CL vs AL in spring and winter among the demographic categories. In autumn, only the relationship CL vs TL was significant (ANCOVA, $\mathrm{p}<0.05$ ), and in summer there were no significant differences (ANCOVA, $p>0.05$, Tab. III).

In spring, all demographic categories showed a negative allometric growth. In summer, the allometric growth was positive for the relationship CL vs TL, and negative for CL vs AL. For the relationship CL vs AL, the allometric growth was negative in autumn. As for CL vs TL, juveniles showed a negative allometry, and males and females showed an isometric growth. In winter, juveniles showed isometric growth in CL vs TL and CL vs AL, while males and females showed a negative allometric growth (Tab. IV).
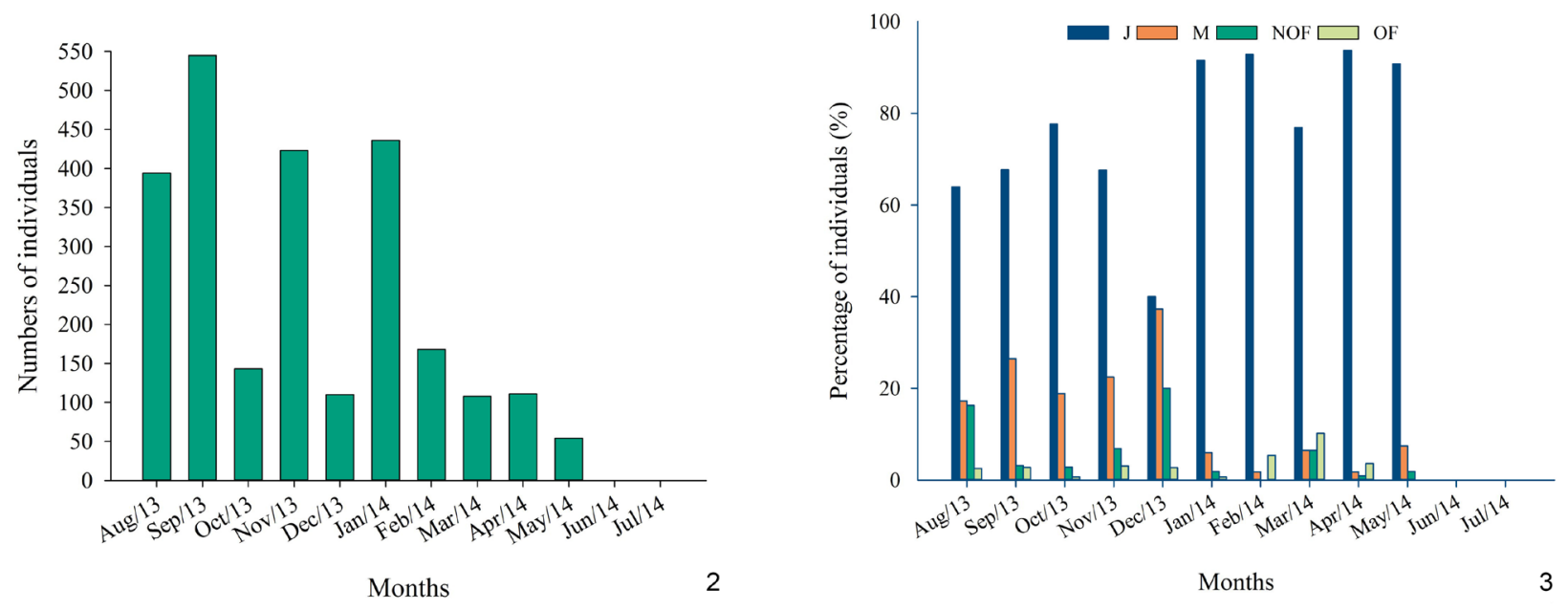

Figs 2, 3. Percentage of total abundance (Fig. 2) and juveniles, males, non-ovigerous females and ovigerous females (Fig. 3) of Macrobrachium amazonicum (Heller, 1862) along the study period (J, juveniles; M, males; NOF, non-ovigerous female; OF, ovigerous females). 
Tab. I. Number of individuals (n), minimum (Min), maximum (Max), mean and Standard deviation (SD) carapace length of Macrobrachium amazonicum (Heller, 1862).

\begin{tabular}{lcccc}
\hline \multirow{2}{*}{ Groups } & & \multicolumn{3}{c}{ Carapace length (mm) } \\
\cline { 3 - 5 } & $\mathrm{n}$ & Min & Max & Mean \pm SD \\
\hline Juveniles & 1853 & 1.44 & 6.03 & $4.2 \pm 1.1$ \\
Males & 417 & 6.08 & 9.60 & $6.7 \pm 0.7$ \\
Females & 153 & 6.08 & 10.24 & $7.2 \pm 0.9$ \\
Ovigerous females & 69 & 6.08 & 10.72 & $8.0 \pm 1.0$ \\
Total & 2492 & 1.44 & 10.72 & $4.9 \pm 1.6$ \\
\hline
\end{tabular}
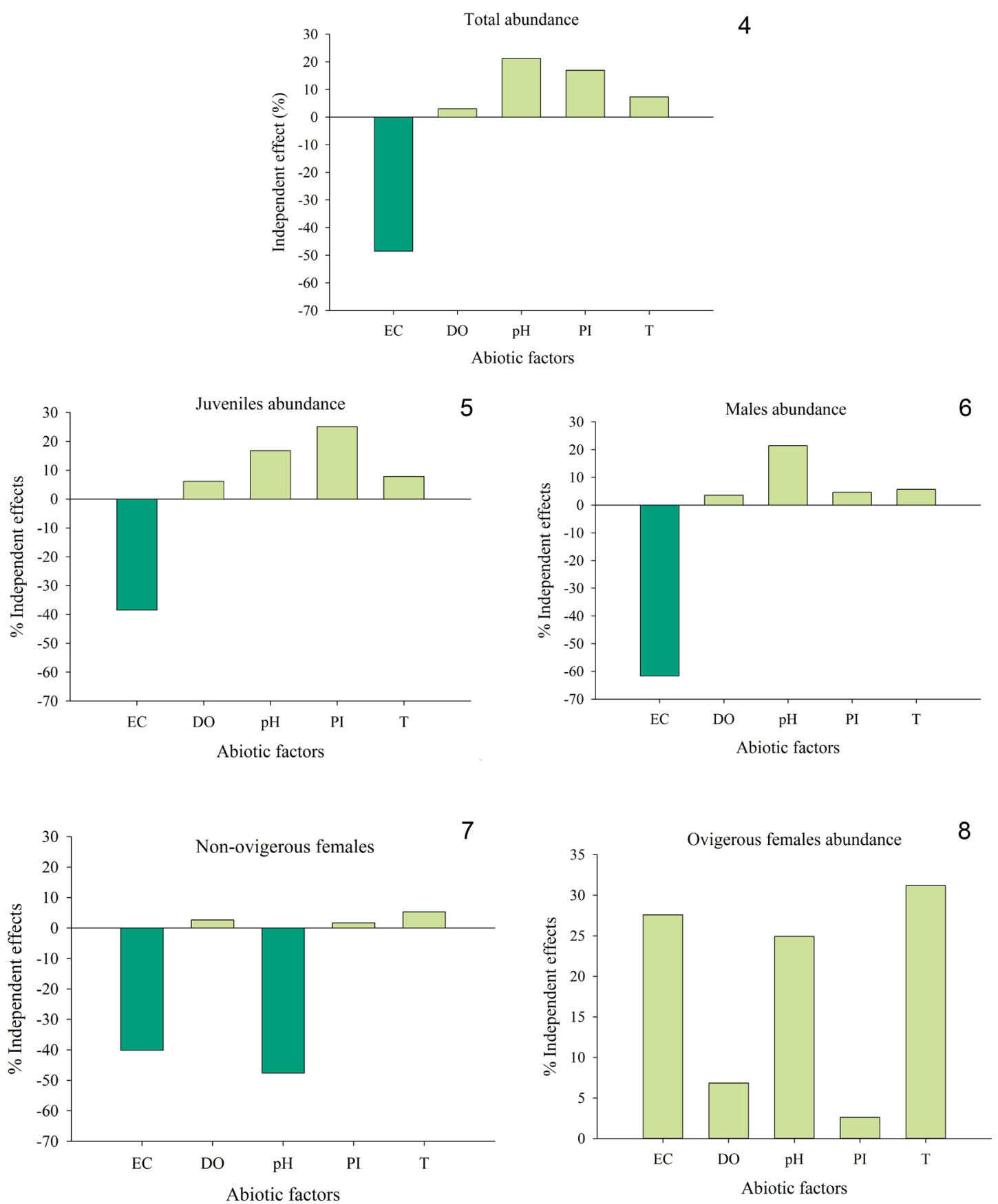

Figs 4-8. Percentage distribution of the independent effect of the abiotic factor on the total abundance (Fig. 4), and on the abundance by demographic category (Figs 5-8) of Macrobrachium amazonicum (Heller, 1862). Grey bars indicate a significant effect ( $<<0.05$ ), determined by the randomization test. Positive and relative relationships are shown by the bars above and under the horizontal axis, respectively (EC, conductivity; DO, dissolved oxygen; PI, precipitation; T, water temperature). 
Tab. II. Abiotic factors at the study site, at each sampling occasion (EC, conductivity; DO, dissolved oxygen; PI, precipitation; T, water temperature; $\mathrm{SD}$, standard deviation).

\begin{tabular}{|c|c|c|c|c|c|}
\hline Month & $\begin{array}{c}\text { EC } \\
\left(\mu \mathrm{Scm}^{1}\right)\end{array}$ & $\begin{array}{c}\mathrm{DO} \\
\left(\mathrm{mg} 1^{1}\right)\end{array}$ & $\mathrm{pH}$ & $\begin{array}{c}\text { PI } \\
(\mathrm{mm})\end{array}$ & $\begin{array}{c}\mathrm{T} \\
\left({ }^{\circ} \mathrm{C}\right) \\
\end{array}$ \\
\hline August 2013 & 14.0 & 1.6 & 6.1 & 1.9 & 24.6 \\
\hline September 2013 & 15.0 & 1.6 & 6.7 & 64.4 & 25.6 \\
\hline October 2013 & 21.0 & 1.7 & 7.9 & 85.6 & 30.7 \\
\hline November 2013 & 18.0 & 1.6 & 7.6 & 173.4 & 30.5 \\
\hline December 2013 & 27.0 & 3.4 & 7.6 & 162.2 & 30.7 \\
\hline January 2014 & 30.0 & 4.7 & 7.8 & 249.3 & 29.6 \\
\hline February 2014 & 35.0 & 6.0 & 8.0 & 34.4 & 31.6 \\
\hline March 2014 & 37.0 & 1.5 & 7.7 & 77.9 & 30.1 \\
\hline April 2014 & 41.0 & 1.6 & 7.4 & 122.8 & 24.8 \\
\hline May 2014 & 40.0 & 3.0 & 7.3 & 20.1 & 20.9 \\
\hline June 2014 & 39.0 & 1.5 & 7.1 & 3.7 & 21.2 \\
\hline July 2014 & 35.0 & 1.3 & 7.8 & 45.3 & 20.0 \\
\hline Average \pm SD & $29.3 \pm 10.0$ & $2.5 \pm 1.5$ & $7.4 \pm 0.5$ & $86.7 \pm 76.5$ & $26.7 \pm 4.3$ \\
\hline
\end{tabular}

Tab. III. Summary of the analysis of covariance of the growth patterns of Macrobrachium amazonicum (Heller, 1862) throughout the seasons (CL, carapace length; TL, total length; AL, abdomen length; SS, sum of squares; d.f., degrees of freedom; MS, mean square). Statistically significant at $\mathrm{p}<0.05(*)$.

\begin{tabular}{|c|c|c|c|c|c|c|}
\hline Season & Variables & SS & d.f. & MS & $\mathrm{F}$ & $p$ \\
\hline \multirow{2}{*}{ Spring } & CL x TL & 0.035 & 2 & 0.017 & 14.115 & $*<0.001$ \\
\hline & CL x AL & 0.037 & 2 & 0.018 & 9.672 & $*<0.001$ \\
\hline \multirow{2}{*}{ Summer } & CL x TL & 0.006 & 2 & 0.003 & 1.640 & 0.195 \\
\hline & CL x AL & 0.007 & 2 & 0.003 & 0.967 & 0.381 \\
\hline \multirow{2}{*}{ Autumn } & CL x TL & 0.006 & 2 & 0.003 & 3.139 & $* 0.046$ \\
\hline & CL x AL & 0.010 & 2 & 0.005 & 2.893 & 0.058 \\
\hline \multirow{2}{*}{ Winter } & CL x TL & 0.336 & 2 & 0.168 & 27.739 & $*<0.001$ \\
\hline & CL x AL & 0.729 & 2 & 0.365 & 30.235 & $*<0.001$ \\
\hline
\end{tabular}

Tab. IV. Linear equations, calculated per season, based on the carapace length (CL, in mm). Values shown as natural logarithms (N, number of individuals; $\mathrm{J}$, juveniles; F, females; M, males; CL, carapace length; TL, total length; AL, abdomen length; $\mathrm{R}^{2}$, determination coefficient; $b$, regression coefficient. Statistically significant at $\mathrm{p}<0.05(*)$. Allometric level: negative allometry $(-)$, positive allometry $(+)$, isometric $(=)$

\begin{tabular}{|c|c|c|c|c|c|c|c|c|}
\hline Seasons & Groups & $\mathrm{N}$ & Variables & Linear equation & $\mathrm{R}^{2}$ & $\mathrm{~b}$ & $\mathrm{t}(\mathrm{b}=1)$ & $\begin{array}{c}\text { Allometric } \\
\text { level }\end{array}$ \\
\hline \multirow{6}{*}{ Spring } & \multirow{2}{*}{$\mathrm{J}$} & \multirow{2}{*}{441} & CL x TL & $\mathrm{TL}=1.63+0.88 \mathrm{CL}$ & 0.87 & 0.8789 & 7.5 & - \\
\hline & & & CL x AL & $\mathrm{AL}=-1.17-0.84 \mathrm{CL}$ & 0.80 & -0.8371 & 8.5 & - \\
\hline & \multirow{2}{*}{$\mathrm{F}$} & \multirow{2}{*}{72} & CL x TL & $\mathrm{TL}=1.68+0.85 \mathrm{CL}$ & 0.87 & 0.8915 & 3.0 & - \\
\hline & & & CL x AL & $\mathrm{AL}=-1.22-0.80 \mathrm{CL}$ & 0.79 & -0.8385 & 3.2 & - \\
\hline & \multirow{2}{*}{ M } & \multirow{2}{*}{163} & CL x TL & $\mathrm{TL}=1.67+0.85 \mathrm{CL}$ & 0.91 & 0.7752 & 7.4 & - \\
\hline & & & CL x AL & $\mathrm{AL}=-1.23-0.81 \mathrm{CL}$ & 0.85 & -0.6584 & 6.8 & - \\
\hline \multirow{3}{*}{ Summer } & \multirow{3}{*}{$\begin{array}{l}J \\
F\end{array}$} & 616 & & & & & & \\
\hline & & 38 & CL x TL & $\mathrm{TL}=1.51+0.93 \mathrm{CL}$ & 0.98 & 0.9344 & 14.0 & + \\
\hline & & 36 & CL x AL & $\mathrm{AL}=-1.02-0.89 \mathrm{CL}$ & 0.97 & -0.8933 & 18.3 & - \\
\hline \multirow{6}{*}{ Autumn } & J & 153 & CL x TL & $\mathrm{TL}=1.55+0.91 \mathrm{CL}$ & 0.96 & 0.9080 & 6.4 & - \\
\hline & $\mathrm{F}$ & 6 & CL x TL & $\mathrm{TL}=1.09+1.12 \mathrm{CL}$ & 0.95 & 1.1239 & $-0.9^{*}$ & $=$ \\
\hline & M & 6 & CL x TL & $\mathrm{TL}=1.57+0.92 \mathrm{CL}$ & 0.98 & 0.9187 & 1.2 & $=$ \\
\hline & $\mathrm{J}$ & \multirow{3}{*}{165} & \multirow{3}{*}{ CL x AL } & \multirow{3}{*}{$\mathrm{AL}=-1.06-0.87 \mathrm{CL}$} & \multirow{3}{*}{0.97} & \multirow{3}{*}{-0.8735} & \multirow{3}{*}{10.8} & \multirow{3}{*}{-} \\
\hline & $\mathrm{F}$ & & & & & & & \\
\hline & M & & & & & & & \\
\hline \multirow{6}{*}{ Winter } & \multirow{2}{*}{$\mathrm{J}$} & \multirow{2}{*}{619} & CL x TL & $\mathrm{TL}=1.23+1.11 \mathrm{CL}$ & 0.85 & 1.1076 & $-5.3 *$ & $=$ \\
\hline & & & $\mathrm{CL} \times \mathrm{AL}$ & $\mathrm{AL}=-0.59-1.16 \mathrm{CL}$ & 0.75 & -1.1602 & $-5.9^{*}$ & $=$ \\
\hline & \multirow{2}{*}{$\mathrm{F}$} & \multirow{2}{*}{104} & CL x TL & $\mathrm{TL}=1.74+0.79 \mathrm{CL}$ & 0.77 & 0.7942 & 4.9 & - \\
\hline & & & CL x AL & $\mathrm{AL}=-1.33-0.71 \mathrm{CL}$ & 0.54 & -0.7061 & 4.5 & - \\
\hline & \multirow{2}{*}{ M } & \multirow{2}{*}{210} & CL x TL & $\mathrm{TL}=1.86+0.75 \mathrm{CL}$ & 0.57 & 0.7496 & 5.6 & - \\
\hline & & & CL x AL & $\mathrm{AL}=-1.50-0.64 \mathrm{CL}$ & 0.34 & -0.6396 & 5.9 & - \\
\hline
\end{tabular}




\section{DISCUSSION}

In the present study it was possible to note important variations on the abundance of $M$. amazonicum, mainly related to the high number of juvenile individuals, and how a specific ecosystem, as the lateral lagoon, might modulate these variations, evidencing specific influences of abiotic factors, as conductivity and $\mathrm{pH}$, on such abundance.

Possibly, the high abundance of juveniles might be related to the sampling method, which was performed on Eichhornia macrophyte banks. ODINETZ-COLLART \& Moreira (1993), in their study in Central Amazon (Careiro island), also observed an abundance of small animals in association with macrophyte banks. Here, this vegetation can provides a range of microhabitats for M. amazonicum, essential for its protection against predators, as observed by ODINETZ-COLLART (1993) in a study about larvae abundance of the same species, reinforcing the importance of these macrophyte banks during the ontogenetic development of the M. amazonicum. Also, the particulate material and organic debris present in the roots of such macrophytes are considered as diet items of some organisms, especially invertebrates (PASCHOAL et al., 2013), contributing, possibly, to the growth of the present species. In this sense, protection and food availability can favor the occurrence not only of juveniles but also of adults, which use these resources for their survival.

Different from juveniles, which were abundant throughout the study period, adult males and females were more abundant only in December 2013. Among some assumptions, differences in the life cycle of juveniles and adults might may influence such results. Although the juveniles are able to walk on the substrate, they are often found near the surface (BIALETZKI et al., 1997), while adults are benthic and live associated to the substrate (MACIEL \& VALENTI, 2009), allowing them to live distant from the margin, in deeper areas. Possibly, the sampling carried out in macrophytic banks present only on the margins of the Mangueira lagoon may have contributed to such juvenile selectivity. Another important factor would be the reproductive activity, in which the animals become more active in the search of their pairs for copulation (MATTOS et al., 2009), and, consequently, became more susceptible to capture (LomBARDI et al., 1996).

In relation to the total abundance of M. amazonicum, the greatest abundances were observed during winter, spring and summer. It is important to observe that during the first and the last two seasons, the lowest and the highest precipitation and dissolved oxygen values were recorded. In general, the precipitation might contribute to the abundance of the species. BIALETZKI et al. (1997) studied the same species in Paraná State and found the highest number of individuals, mainly juveniles, in the month of highest precipitation. According to MatTos et al. (2009), this may occur due to the increase in water oxygenation caused by the rainfall, favoring the development of the individuals, as observed in the present study during spring and summer seasons. On the other hand, low precipitation or low water levels, would decrease oxygenation and, consequently, the metabolic rates of these organisms (Lima et al., 2013). As a result, the animals found in environments with such characteristics might show a smaller body size compared to other populations inhabiting distinct environments, corroborating with the results obtained in the present study.

The relationship between the number of individuals and the abiotic factors (conductivity, dissolved oxygen, $\mathrm{pH}$, precipitation, and temperature) showed that the total abundance and the abundance of juveniles, males and non-ovigerous females were correlated, significantly, with conductivity, demonstrating the importance of this factor for the abundance of M. amazonicum at the present study. According to Welcomme (1985), conductivity measures the total amount of ions in the water. Soon, the ion availability is relevant for crustacean growth, since the need for calcium is high due to the regular molts of the exoskeleton (GreenawaY, 1985). Besides calcium, the phosphorous ions are also essential for the synthesis of the new exoskeleton during the molt process (WANG et al., 2003). However, the relationship between the abundance of M. amazonicum and the conductivity was negative. The lack of connectivity between the lateral lagoon and other bodies of water, except during the raining season, can either raise or lower the concentration of ions essential for the development of the species, that were not measured in the present study and could influenced the obtained result.

Different from conductivity, $\mathrm{pH}$ measures only the concentration of oxygen ions in the water, and it gets near neutrality when precipitation is high (NAIME \& FAGUNDES, 2005). During most months the $\mathrm{pH}$ was near neutrality, ranging from 6.1 to 8.0 , with mean of $7.4 \pm 0.5$, and yet a negative relationship was observed between the abundance of non-ovigerous females and this abiotic factor. Possibly, the higher abundance of them obtained in August and September, months with the lowest $\mathrm{pH}$ values recorded, may have influenced this result. In other studies on M. amazonicum, practically all the authors verified the occurrence of the species when the $\mathrm{pH}$ values recorded were similar to those observed in the present investigation (i.e. ODINETZ-COLLART, 1988; Montoya, 2003; SAmpaio et al., 2007), but without significant relationships. So, in future studies it would be important to consider other specific conditions of the present local study, such as hydrography and relief, once they seem to influence the abundance variations of M. amazonicum.

The abiotic factors analyzed here did not correlated significantly with the abundance of ovigerous females. However, it is known that the temperature may be relevant for these individuals, as reported by several studies carried out in Brazil. SiLva et al. (2002) found a high number of ovigerous females in months of higher temperature, as May $\left(27.5^{\circ} \mathrm{C}\right)$, July $\left(27.5^{\circ} \mathrm{C}\right)$, September $\left(29.5^{\circ} \mathrm{C}\right)$, and February $\left(26.5^{\circ} \mathrm{C}\right)$ in the northern. ODINETZ-COLLART (1991), researching in the same region, observed the reproductive peak of M. amazonicum in May, as well as an increase in female abundance in March, June, and November, when the highest temperature values were recorded. For the prawn M. jelskii, LiMA et al. (2013) 
found the highest number of ovigerous females in the warmer months, during the raining season (from December to May), with a peak in February. According to MATTos et al. (2009), high temperatures, in addition to contributing to gonadal development, favor the nutrition of larvae and juveniles due to the dietary resources provided by the higher density of plankton. Corroborating with these results, the greater abundances of ovigerous females were recorded during the warmer months of February $\left(31.6^{\circ} \mathrm{C}\right)$ and March $\left(30.1^{\circ} \mathrm{C}\right)$ 2014, evidencing the importance of temperature regarding the reproductive parameters of the species.

According to MASHIKO (2000), environmental factors can influence the different growth rates among populations of caridean prawns. In the present study, all morphometric relationships in summer, and the carapace length and the abdomen length relationship in the autumn were expressed by the same equation for all demographic categories, with different allometric levels. According to MoRaEs-RIODADES $\&$ VALENTI (2002), this suggests that the growth pattern of the body parts does not change throughout the post-larva development. However, the positive allometry between the carapace length and the total length observed in the summer may be related to the reproductive period of the species. In this season, the growth of the total length in relation to the carapace length increases, possibly due to incubation of the eggs attached to the pleopods of the females (SiLva et al., 2007). BeNTES et al. (2011), Freire et al., (2012), e NóBrEGA et al. (2014) also found a positive allometric relationship between carapace length and total length of M. amazonicum, but when both sexes were grouped.

On the other hand, in the spring, the different equations found for juveniles, females and males, demonstrated a differential growth of the body structures. All demographic categories showed a cephalothorax growth proportionally higher than the total length and abdomen length, evidenced by a negative allometry. Similar results were found by Moraes-Riodades \& VALENTI (2002), which associated such variation to the increase of the cephalothorax because the vital organs of prawns are located in this region. These individuals probably can benefit from the availability of food resources due to the onset of the rainy season in the spring, increasing their body size in order to successfully perform later events, such as reproductive events.

In general, the population of M. amazonicum here studied presented similar characteristics to other populations along its distribution range, as the high number of juveniles and the smaller size of males compared to females, despite the scarce information available about this species in some regions. It is important to note that, despite the accumulated knowledge about the biology of the species, the present study provides information that expand the knowledge on the plasticity of $M$. amazonicum, considering the studied local - a lateral lagoon formed due to the construction of reservoirs and its interactions. In this way, the obtained results can be used in comparative studies among natural populations in order to favor the comprehension of the vast occurrence of the species and its adaptations to each specific environment, contributing to the elaboration of conservation and management guidelines for M. amazonicum and for the environment where it inhabits.

Acknowledgements. We would like to thank the owner of the Mangueira Lagoon Farm for allowing our sampling, to Mr. Laurindo José Bonatto Júnior for his support during sampling, to the researcher Antonio C. M. Queiroz for helping with the analyses in R, and to the Coordenação de Aperfeiçoamento de Pessoal de Nivel Superior (CAPES - Financing Code 001) for the financial support. We thank the Laboratory of Bioecology and Systematics of Crustaceans Laboratory (LBSC) of the Universidade de São Paulo - USP, for the identification of the prawns, the colleagues of the Laboratory of Carcinology, and the Universidade Federal de Lavras (UFLA), for providing the required infrastructure. All samplings were conducted in compliance with current state and federal laws.

\section{REFERENCES}

Baumgartner, G.; Nakatani, K.; Gomes, L. C.; Bialetzki, A.; Sanches, P. V. \& MAKraKis, M. C. 2004. Identification of spawning sites as natural nurseries in the Upper Paraná River. Environmental Biology of Fish 71:115-125.

Bentes, B.; Martinelli, J. M.; Souza, L. S.; Cavalcante, D. V.; Almeida, M. C. \& IsAaC, V. J. 2011. Spatial distribution of the Amazon River prawn Macrobrachium amazonicum (Heller, 1862) (Decapoda, Caridea, Palaemonidae) in two perennial creeks of an estuary on the northern coast of Brazil (Guajará Bay, Belém, Pará). Brazilian Journal of Biology 71:925-935.

Bialetzki, A.; Nakatani, K.; Baumgartner, G. \& Bond-Buckup, G. 1997. Occurrence of Macrobrachium amazonicum (Heller) (Decapoda, Palaemonidae) in Leopoldo's inlet (Ressaco do Leopoldo), upper Paraná River, Porto Rico, Paraná, Brasil. Revista Brasileira de Zoologia 14(2):379-390.

Bicudo, D. C.; Ferragut, C.; Crossetti, L. O. \& Bicudo, C. E. M. 2006 Efeitos do represamento sobre a estrutura da comunidade fitoplanctônica do Reservatório de Rosana, baixo rio Paranapanema, Estado de São Paulo. In: Nogueira, M. G.; Henry, R. \& Jorcin, A. eds. Ecologia de reservatórios: impactos potenciais, ações de manejo e sistemas em cascata. São Carlos, RiMa Editora, p. 349-377.

Buckup, L. \& Bond-Buckup, G. 1999. Os crustáceos do Rio Grande do Sul. Porto Alegre, Editora UFRGS. 503p.

Chevan, A. \& Sutherland, M. 1991. Hierarchical Partitioning. The American Statistician 45:90-96.

CLIMATE-DATA.ORG. 2018. Available at $<$ https://pt.climate-data.org/ location/176364/>. Accessed on 17 August 2018.

Freire, J. L.; MArques, C. B. \& Silva, B. B. 2012. Estrutura populacional e biologia reprodutiva do camarão-da-Amazônia Macrobrachium amazonicum (Heller, 1862) (Decapoda: Palaemonidae) em um estuário da região nordeste do Pará, Brasil. Brazilian Journal of Aquatic Science and Technology 16(2):65-76.

García-DÁvila, C. R. \& Magalhães, C. 2003. Revisão taxonômica dos camarões de água doce (Crustacea: Decapoda: Palaemonidae, Sergestidae) da Amazônia Peruana. Acta Amazonica 33(4):663-686.

Greenaway, P. 1985. Calcium balance and moulting in the crustacea. Biological Reviews 60(3):425-454.

Hartnoll, R. G. 1978. The determination of relative growth in Crustacea. Crustaceana 34:281-293.

HENRY, R. 1999. Ecologia de Reservatórios: Estrutura, função e aspectos sociais. Botucatu, FAPESP/FUNDIBIO. 632p.

Henry, R.; Panarelli, E. A.; Casanova, S. M. C.; Suiberto, M. \& Afonso, A. A. O. 2006. Interações hidrológicas entre lagoas marginais e o Rio Paranapanema na zona de sua desembocadura na Represa de Jurumirim. In: Nogueira, M. G.; Henry, R. \& Jorcin, A. Eds. Ecologia de reservatórios: impactos potenciais, ações de manejo e sistemas em cascata. São Carlos, RiMa Editora, p. 57-82.

Holthuis, L. B. 1952. A general revision of the Palaemonidae (crustacea Decapod Natantia) of the Americas. II. The subfamily Palaemonidae. Allan Hancock Foundation Publications, Occasional Paper 12:1-396.

Huxley, J. S. 1950. Relative growth and form transformation. Proceedings of Royal Society of London 137(B):465-469. 
IBGE - Instituto Brasileiro de Geografia e Estatística. 1990. Divisão Regional do Brasil em Mesorregiões e Microrregiões Geográficas. Rio de Janeiro, IBGE. 135p.

Kennedy, R. H.; Tundisi, J. G.; Straskraba, V.; Lind, O. T. \& Hejzlar, J. 2003. Reservoirs and the limnologist's growing role in sustainable water resource management. Hydrobiologia 504:11-12.

Lima, D. P.; Silva, L. M. A. \& LirA, A. C. S. 2013. Biologia populacional de Macrobrachium jelskii (Miers, 1778) (Crustacea, Decapoda, Palaemonidae) em uma planície inundável na Amazônia Oriental, Brasil. Biota Amazônia 3(2):11-22.

LOMBARDI, J. C.; LOBÃo, V. L. \& Roverso, E. A. 1996. Estudos populacionais de Macrobrachium birai Lobão, Melo e Fernandes e Macrobrachium petronioi Melo, Lobão e Fernandes das regiões de Cananéia e Juréia (SP-Brasil): II. Dinâmica do crescimento. Boletim do Instituto de Pesca 23:47-54.

Maciel, C. R. \& VAlenti, W. C. 2009. Biology, fisheries, and aquaculture of the Amazon River prawn Macrobrachium amazonicum: a review. Nauplius 17:61-79.

MaCNALLY, R. 2000. Regression and model-building in conservation biology, biogeography and ecology: the distinction between - and reconciliation of-'predictive' and 'explanatory' models. Biodiversity and Conservation 9:655-671.

MaCNaLLY, R. 2002. Multiple regression and inference in ecology and conservation biology: further comments on identifying important predictor variables. Biodiversity and Conservation 11:1397-1401.

Mantelatto, F. L. M. \& Barbosa, L. R. 2005. Population structure and relative growth of freshwater prawn Macrobrachium brasiliense (Decapoda, Palaemonidae) from São Paulo State, Brazil. Acta Limnologica Brasiliensia 17:245-255.

MASHIKO, K. 2000. Variations in body size of individuals at sexual maturity among local populations of the freshwater prawn Macrobrachium nipponense (de Haan), with special reference to freshwater colonization. Crustacean Research 29:20-26.

Mattos, L. A.; Oshiro, L. M. \& MarCONI, Y. 2009. Estrutura populacional de Macrobrachium potiuna (Crustacea, Palaemonidae) no Rio do Moinho, Mangaratiba, Rio de Janeiro, Brasil. Biota Neotropica 9:81-86.

Melo, G. A. S. 2003. Manual de identificação dos Crustacea Decapoda de água doce do Brasil. Edições Loyola, São Paulo. 429p.

Montoya, J. V. 2003. Freshwater shrimps of the genus Macrobrachium associated with roots of Eichhornia crassipes (Water Hyacinth) in the Orinoco Delta (Venezuela). Caribbean Journal of Science 39(1):155159.

Moraes-Riodades, P. M. C. \& Valenti, W. C. 2002. Crescimento relativo do camarão canela Macrobrachium amazonicum (Heller) (Crustacea, Decapoda, Palaemonidae) em viveiros. Revista Brasileira de Zoologia 19:1169-1176.

Moraes-Valenti, P.; Morais, P. A.; Preto, B. L. \& Valenti, W. C. 2010. Effect of density on population development in the Amazon River prawn Macrobrachium amazonicum. Aquatic Biology 9:291-301.

Naime, R. \& Fagundes, R. S. 2005. Controle da qualidade da água do Arroio Portão Portão, RS. Pesquisas em Geociências 32(1):27-35.

NóbreGa, P. S. V.; Bentes, B. \& Martinelli-Lemos, J. M. 2014. Population structure and relative growth of the Amazon shrimp Macrobrachium amazonicum (Heller, 1862) (Decapoda: Palaemonidae) on two islands in the fluvial-estuarine plain of the Brazilian Amazon. Nauplius 22(1):13-20.

Nogueira, M. G.; Jorcin, A.; Vianna, N. C. \& Britto, Y. C. T. 2006. Reservatórios em cascata e os efeitos na limnologia e organização das comunidades bióticas (fitoplâncton, zooplâncton e zoobentos) - um estudo de caso no rio Paranapanema. In: NogueIRA, M. G., Henry, R. \& JORCIN, A. eds. Ecologia de reservatórios: impactos potenciais, ações de manejo e sistemas em cascata. São Carlos, RiMa Editora, p.83-125.
ODinetZ-Collart, O. 1988. Aspectos ecológicos do camarão Macrobrachium amazonicum (Heller, 1862) no Baixo Tocantins (PA-Brasil). Memoria Sociedad de Ciencias Naturales La Salle 48(Supl.):341-353.

ODINETZ-COLLaRT, O. 1991. Tucurui dam and the populations of the prawn Macrobrachium amazonicum in the lower Tocantins (PA, Brasil): a four year study. Archive fur Hidrobiologie 122(2):213-227.

ODinetZ-Collart, O. 1993. Ecologia e potencial pesqueiro do camarãocanela, Macrobrachium amazonicum, na Bacia Amazônica. In: Ferreira, E. J. G.; Santo, G. M.; Leão, E. L. M. \& Oliveira, L. A. eds. Bases científicas para estratégias de preservação e desenvolvimento da Amazônia: Fatos e Perspectivas. Manaus, INPA editora, p. 147-166.

Odinetz-Collart, O. \& Moreira, L. C. 1993. Potencial pesqueiro de Macrobrachium amazonicum, na Amazônia Central (Ilha do Careiro): variação da abundância e do comprimento. Amazoniana 12(3/4):399-413.

Paschoal, L. R. P.; Souza, R. M.; Guimarães, F. J. \& Couto, E. C. G. 2013. Phytophilous caridean shrimps (Atyidae and Palaemonidae) in Salsa River (Canavieiras, Bahia, Brazil). Nauplius 21(1):123-126.

PIECZYNSKA, E. 1995. Habitas e comunidades litorâneas. In: JorgEnSEN, S. E. \& LOFFER, H. eds. Diretrizes para o gerenciamento de lagos: gerenciamento de litorais lacustres. Otsu, Shiga, Itagura-kabo Co., p. $40-76$.

Pileggi, L. G.; Magalhães, C.; Bond-Buckup, G. \& Mantelatto, F. L. M. 2013. New records and extension of the known distribution of some freshwater shrimps in Brazil. Revista Mexicana de Biodiversidad 84(2):563-574

R Development Core Team. 2018. R: A language and environment for statistical computing. R Foundation for Statistical Computing, Vienna, Austria. Available at $<$ https://www.R-project.org/>. Accessed on 12 April 2018

Sampaio, C. M. S.; Silva, R. R.; Santos, J. A. \& Sales, S. P. 2007. Reproductive cycle of Macrobrachium amazonicum females (Crustacea, Palaemonidae). Brazilian Journal of Biology 67(3):551-559.

SendaCZ, S. \& MonTEIRO-JÚNIOR, A. J. 2003. Zooplâncton e Características Limnológicas da Planície de Inundação do Rio Paraná. In: Raoul, H. ed. Ecótonos nas Interfaces dos Sistemas Aquáticos. São Carlos, Rima Editora, p. 129-160.

Silva, K. C. A.; SouZA, R. A. L. \& CinTRA, I. H. A. 2002. Camarão-cascudo Macrobrachium amazonicum (Heller, 1862) (Crustacea, Decapoda, Palaemonidae) no município de Vigia, Pará, Brasil. Boletim TécnicoCientífico do CEPNOR 2:41-73.

Silva, M. C. N.; Frédou, F. L. \& Rosa-Filho, J. S. 2007. Estudo do crescimento do camarão Macrobrachium amazonicum (Heller,1862) da ilha de Combú, Belém, estado do Pará. Amazônia: Ciência e Desenvolvimento 2(4):85-104.

TUNDISI, J. G. 1988. Impactos ecológicos da construção de represas: aspectos específicos e problemas de manejo. In: TUNDISI, J. G. ed. Limnologia e manejo de represas. Série: Monografias em limnologia. São Paulo, ACIESP Editora, p.1-75.

Tundisi, J. G. \& StraŠKRABA, M. 1999. Theoretical Reservoir Ecology and its Applications. Leiden, Backhuys Publishers. 586p.

Vergamini, F. G.; Pileggi, L. G. \& Mantelatto, F. L. M. 2011. Genetic variability of the Amazon River prawn Macrobrachium amazonicum (Decapoda, Caridea, Palaemonidae). Contributions to Zoology 80(1):67-83.

Walsh, C. \& MacNally R. 2015. Hier.part - Hierarchical Partitioning. R Package version 1.0-4. Available at $<$ http://cran.r-project.org/web/ packages/hier.part/index.html>.

WANG, W. N.; WANG, A. L.; Wang, D. M.; Wang, L. P.; LiU, Y. \& Sun, R.Y. 2003. Calcium, phosphorus and adenylate levels and $\mathrm{Na}+-\mathrm{K}+$-ATPase activities of prawn, Macrobrachium nipponense, during the moult cycle. Comparative Biochemistry and Physiology Part A 134:297-305.

Welcomme, R. L. 1985. River fisheries. FAO Fisheries Technical Papers 262:330.

ZAR, J. H. 1999. Bioestatistical Analysis. New Jersey, Prentice-Hall. 663p. 